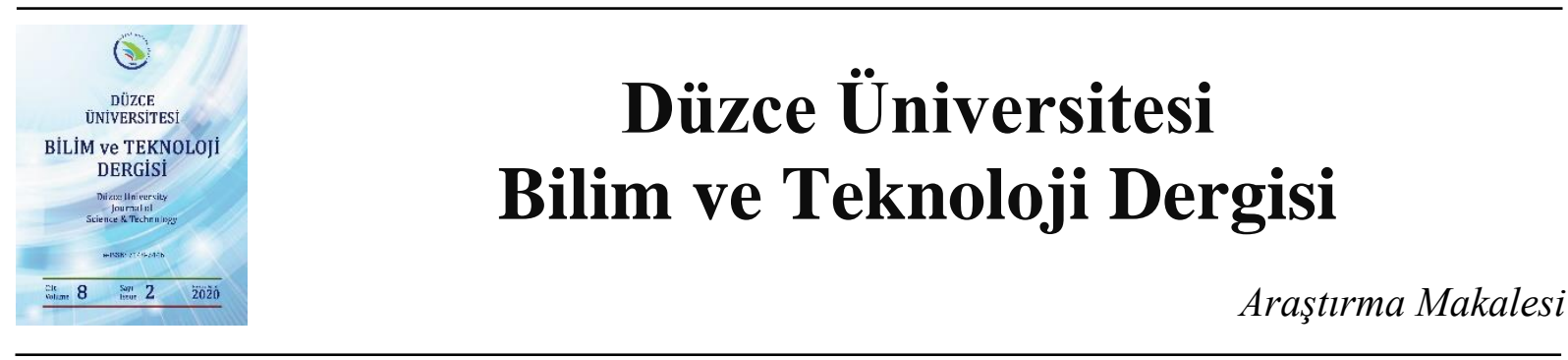

\section{AISI304L ve AISI430 Kalite Paslanmaz Çeliklerin Nokta Direnç Kaynak Kabiliyetine İlave Yapıştırıcının Etkisi}

\author{
(iD) Harun ÇUĞ ${ }^{\text {a,* }}$, iD Fatih DAĞLAR ${ }^{\mathrm{b}}$ \\ ${ }^{a}$ Makine Mühendisliği Bölümü, Mühendislik Fakültesi, Karabük Üniversitesi, Karabük, TÜRKIYYE \\ ${ }^{b}$ Makine Mühendisliği A.B.D Fen Bilimleri Enstitüsü., Karabük Üniversitesi, Karabük, TÜRKIYE \\ * Sorumlu yazarın e-posta adresi: hcug@karabuk.edu.tr
}

DOI: $10.29130 /$ dubited.632999

\begin{abstract}
ÖZET
$\mathrm{Bu}$ çalışmanın amacı, ferritik ve östenitik paslanmaz çeliklerin ilave yapıştırıcı kullanarak elektrik direnç nokta kaynak yöntemi ile birleştirilmesi esnasında değiştirilen bazı kaynak parametrelerinin mekanik ve mikroyapı özelliklerine etkisini araştırmaktır. Çalışmada, AISI 430 ferritik ve AISI 304L kalite östenitik paslanmaz çelikler nokta direnç kaynak yöntemi ile yapıştırıcılı ve yapıştırıcısız olmak üzere birbirleri ile birleştirilmiştir. Kaynak işlemleri; 5, 8, 11 kA kaynak akımı ve 10, 20, 30 periyot kaynak süresinde olmak üzere 9 farklı parametrede yapıştırıcılı ve yapıştırıcısız olarak 2 farklı şekilde gerçekleştirilmiştir. Yapıştırıcılı kaynak numunelerinde Tereson MS 9220 yapıştırıcı malzeme kullanılmıştır. Yapılan deneysel çalışmalar sonucunda; kaynak akımının artması ile buna paralel olarak kaynak çekirdek çapı ve elektrot dalma derinliği artmıştır. İlave yapıştırıcı kullanılan yapıștırıcılı numuneler yapıştırıcısız numunelere göre daha fazla çekme-makaslama dayanımı sağladığ gözlemlenmiştir. Sertlik deneyleri sonucunda en yüksek değerler kaynak çekirdeğinden ölçülmüştür. Mikroyap1 görüntüleri incelendiğinde östenitik kısımlarda yüksek 1sı girdisinden dolayı kaynak çekirdeğinde oluşan tanelerin irileştiği gözlemlenmiştir.
\end{abstract}

Anahtar Kelimeler: Paslanmaz çelik, elektrik direnç nokta kaynă̆ı, adhesiv yapıştırıcı, mikroyapı ve mekanik özellikler

\section{Effect of Additional Adhesive on The Point Resistance Welding Ability of AISI304L and AISI430 Grade Stainless Steels}

\begin{abstract}
The aim of this study was to investigate the effects of some welding parameters on the mechanical and microstructural properties of ferritic and austenitic stainless steels during the combining of electrical resistance point welding method using additional adhesive. In the study, AISI 430 ferritic and AISI 304L quality austenitic stainless steels are combined with each other, with or without glue, by the point resistance welding method. Welding processes; Electrode force of $6 \mathrm{kN}$, welding current of 5, 8, $11 \mathrm{kA}$ and welding time of 10, 20, 30 periods were realized in 2 different ways with and without adhesive in 9 different parameters. Tereson MS 9220 spot weldable adhesive material was used in the adhesive welding samples. As a result of experimental studies; The welding core diameter and the depth of the electrode plunge were increased in parallel with the increase of the welding current. Adhesive samples with additional adhesive were observed to provide more tensile-shear strength than non-adhesive samples. As a result of hardness tests, the highest values were measured from the welding core. When the microstructure images were examined, it was observed that the grains formed in the welding core became larger due to the high heat input in the austenitic parts.
\end{abstract}

Keywords: Stainless steel, Resistance spot welding, Additional adhesive, Microstructure and mechanical properties 


\section{GIRIS}

Endüstriyel amaçlı kullanılan bir çok çelik türü vardır. Bunlar arasında DP, TRIP, TWIP, IF Çeliği en çok kullanılan çelik türleri arasındadır. Her birçelik türünün mikroyapıve mekanik özellikleri ve kullanım bölgeleri farklıdır [1-11]. Fakat korozif özelliklerin ön plana çıktığı sektörlerde paslanmaz çelik kullanılmaktadır [12-14]. Korozyona karşı dayanıklı demir alaşımı olarak tanımlanan paslanmaz çelikler, genel olarak içerisinde \% 12 krom ve \% 1,2 karbon içerirler. Paslanmaz çeliklerin tümünün korozyona karşı meydana gelen direnci yoğun krom oksit yüzeyin oluşmasıyla meydana gelir. Oksidasyonun derine doğru hareketini engelleyen, meydana gelen bu yüzeydir. Oksidasyonun daha derine doğru ilerlemesini engeller. Paslanmaz çelikler 5 gruba ayrllırlar. Bunlar; östenitik, ferritik, martenzitik, çift fazlı dubleks ve çökeltme sertleşmesi uygulanabilen paslanmaz çeliklerdir.

Östenitik paslanmaz çelikler, içerisinde karbon, nikel, azot ve bakır bulundururlar. Bu çelikler en çok ve en yaygın kullanılan paslanmaz çelik türüdür. En yaygın kullanım alanları; eczacılık, gıda, kimya ve petrokimya sanayisidir. AISI 304L, östenitik paslanmaz çelikler arasında en önemli olanıdır. Bunun sebebi bu kalite paslanmaz çelikler çok iyi korozyon direncine sahiptirler ayrıca bu tür paslanmaz çeliklerin diğer bir önemli özelliği, diğer çeliklerin aksine manyetik özellik göstermemesidir. AISI 304L çelikleri AISI 304 göre farkları bakımından daha düşük karbon oranına sahiptirler. Bundan dolayı kaynak kabiliyetleri daha yüksektir.

Ferritik paslanmaz çelikler, içerisinde bileşiminde \% 11 ile \% 28 arasında krom bulunur. Faz dönüşümü göstermedikleri için sertleştirilemeyen paslanmaz çelik olarak bilinirler. Otomotiv sanayisin de, mutfak aletlerin de ve dekoratif uygulamalar da yaygın olarak kullanılmaktadır. AISI 430 içerisindeki krom, azot ve karbon bulundururlar. 430 kalite paslanmaz çelikler mıknatıslanma özelliği gösterirler. Bunun sebebi bileşiminde Nikel bulundurmamalarıdır. Bu çelikler mekanik olarak ortalamanın üzerinde bir mekanik kuvvete sahiptirler.

Paslanmaz çeliklerin farklı kaynak yöntemleriyle birleştirilmesi mümkündür. Bunlardan bazıları; elektrik ark kaynağı, tozaltı ark kaynağı, MIG kaynağı, TIG kaynağı, plazma ark kaynağı ve bu kaynak yöntemlerinin yanı sıra modern kaynak yöntemi olan elektron ışın kaynak yöntemi ile de günümüzde rahatlıkla kaynak yapılabilirler. Paslanmaz çeliklerin birleştirilmesinde farklı kaynak yöntemleri kullanılmasına rağmen özellikle ince sac levhaların birleştirilmesinde elektrik direnç kaynak yöntemleri seri üretime uygunluğu, düşük işçilik giderleri, yüksek kaynak mukavemeti, hızlı bir şekilde imalat yapılabilmesi ve diğer yöntemlere nazaran düzgün bir kaynak görünümü elde edilmesi gibi nedenlerle tercih edilmektedir.

Elektrik direnç nokta kaynağı ile birleştirilen ferritik ve östenitik paslanmaz çelik bağlantılarının mekanik özelliklerinin bilinmesi ve üretilen makine, ekipman ya da konstrüksiyonun daha güvenli kullanılması açısından önemlidir. Elektrik direnç nokta kaynağı ile birleştirilen paslanmaz çeliklerin kaynak bölgesindeki sertlik dağılımı, bağlantının çekme-makaslama dayanımı, kaynak sonrası oluşan çekirdek çap1 ve elektrot dalma derinliği gibi özelliklerin belirlenmesi çok önemlidir. Bu özelliklerin belirlenmesinde en önemli yer kaynak bölgesinin mikroyapısıdır [15-22].

Nokta direnç kaynağı yöntemi ile çeşitli paslanmaz çeliklerin kaynak yapılması sonucunda çeşitli alanlarda kullanılan makine ya da ekipmanın güvenli kullanılmasının önemi büyüktür. Nokta direnç kaynağı ile kaynaklanan malzemelerde delinme ve erime gibi sorunlar ortaya çıkmaktadır. Bunun sebebi elektrot tiplerin boyutu ve kullanılan amper yükünün malzemeye uygun olmaması gibi nedenlerdir. $\mathrm{Bu}$ nedenle araştırmalar genellikle farklı çelik sacların ya da farklı metallerin kaynak kabiliyetlerinin araştırılması ya da uygulanan kaynak yönteminin malzemeler üzerindeki etkisi incelenmesidir [23]. Kocabekir ve ark. tarafından Isı girişi, kaynak atmosferi ve kaynak soğutma koşullarının 316L östenitik paslanmaz çeliğin direnç nokta kaynaklanabilirliğine etkisi incelemiş ve kaynaklı numunelerin son mekanik özelliklerinin, kaynak zamanını ve kaynak atmosferini bilerek kullanılan işlemin parametreleriyle doğrudan ilişkili olduğu tespit etmişlerdir [24]. S. M. Manladan ve ark. kaynak lehimleme modunda magnezyum alaşımlarının ve östenitik paslanmaz çelik bağlantılarının nokta direnç 
kaynaklı mikroyapısı ve mekanik özellikleri incelemişler ve incelemeleri doğrultusunda Bir AZ31 Mg alaşımı ve 316L östenitik paslanmaz çelik direnç nokta kaynağ1 ve direnç elemanı kaynağ 1 ile birleştirmişler. Direnç nokta kaynağı bağlantılarının, $\mathrm{Mg}$ alaşımı erimiş ve katı çelik üzerinde yayıldığı, yalnızca Mg alaşımı içinde bir çekirdek oluşturan kaynak lehimleme modu ile üretildiği kanısına varmışlardır [25]. Hayat, kaplamalı ve kaplanmamış DP 600 çeliğin yapışkan bağlanma, direnç nokta kaynağı ve yapışkan kaynak bağlama özelliklerinin karşılaştırılması üzerine çalışma yapmış ve bu çalışma sonucunda yapışkan kaynak yapıştırma derzleri yapışkan bağlanma ve direnç nokta kaynağı derzlerinden daha yüksek olduğu ve kopmuş bölgelerin SEM analizi, numunelerde çukur bir yapı ve sünek bir kırılma olduğu tespit edilmiştir [26]. Hayat, çift fazlı çeliklerin nokta direnç kaynağında mikroyapısı ile kaynak süresinin mekanik özelliklerine etkisini incelemiş ve araştırma sonucunda nokta kaynağında sabit akım şiddetinde ve sabit elektrot basıncında kaynak süreleri artışıyla çekme makaslama mukavemet değerlerinin arttığ belirlenmiş ve kaynak akımı ve elektrot basıncı sabit kalmasına rağmen kaynak süresindeki artışla, kaynak bölgesinde 1sı girdisinin arttığı bununla birlikte kaynak iz çapı, çökme ve birleştirme ara yüzey kesit kalınlığı artı̆̆ kanısına varmıştır.

Mevcut literatürde elde edilen veriler, birbirinden farklı yada aynı tip malzemelerin nokta direnç kaynaklanabilirliği, nokta direnç kaynağının yüzey kalitesi ve mikroyapı analizine yöneliktir. Bu çalışmada paslanmaz çeliklerin nokta direnç kaynak kabiliyetlerine ilave yapıştırıcı ile mikroyapı ve mekanik özelliklerinde oluşacak farklılıklar tespit edilmiştir. Bu çalışmada endüstride oldukça önemli ve kullanımı yaygın olan AISI 430 temel ferritik kalite ile yüksek sıcaklık malzemesi olarak bilinen AISI 304L östenitik paslanmaz çelik sacların nokta direnç kaynağıyla kaynaklı bağlantıları yapılmıştır. Ayrıca nokta direnç kaynak uyumlu ilave yapıştırıcı (Tereson MS 9220) kullanılarak bu birleştirmelerin mekanik özelliklerine etkisi incelenmiş, çeşitli deney koşullarında mevcut parametreleri değiştirilerek araştırılmıştır.

\section{DENEY CALISMALAR}

Bu çalışmada, AISI 304L (X2CrNi18-9) östenitik ve AISI 430 (X6Cr17) kalite ferritik paslanmaz çelik malzemeler seçilmiştir. Deneyde kullanılacak olan çelik malzemelerin kimyasal bileşimleri Tablo 1'de verilmiştir.

Tablo 1. Çelik malzemelerin kimyasal bileşimleri

\begin{tabular}{cccccccc} 
Malzeme & \multicolumn{8}{c}{ Kimyasal Bileşim (\%) } \\
\cline { 2 - 8 } (ASTM standardı) & $\mathbf{C}$ & $\mathbf{M n}$ & $\mathbf{P}$ & $\mathbf{S}$ & $\mathbf{S i}$ & $\mathbf{C r}$ & $\mathbf{N i}$ \\
\hline AISI 304L & 0.03 & 2.0 & 0.045 & 0.03 & 0.75 & $18-20$ & $8-10$ \\
\hline AISI 430 & 0.12 & 1.0 & 0.045 & 0.03 & 1.0 & $16-18$ & 0.75
\end{tabular}

Ayrıca deneyde kullanılacak olan yapıştırıcı malzeme Tereson MS 9220 marka yapıştırıcı malzeme kullanılmıştır. Yapıştırıcının seçiminde nokta kaynak kabiliyeti ile uyumluluk esas alınmıştır. Çelik parça yapıştırılmasında da kullanılan özel bir yapıştırıcı türüdür. Kaynak işlemi için 1,5 mm kalınlığında $1000 \times 2000 \mathrm{~mm}$ ebatlarında AISI 304L ve AISI 430 kalite paslanmaz çelik sac levha 30x100 mm ebatlarında giyotin makas yardımıyla kesilerek hazırlanmıştır. Kaynak, paslanmaz çelik sac malzemelerimiz üst üste bindirilecek şekilde yapılmıştır. Kaynak yapılacak olan çelik malzemelerin boyutları ve kaynak sonrası boyutları Şekil 1'de verilmiştir. 


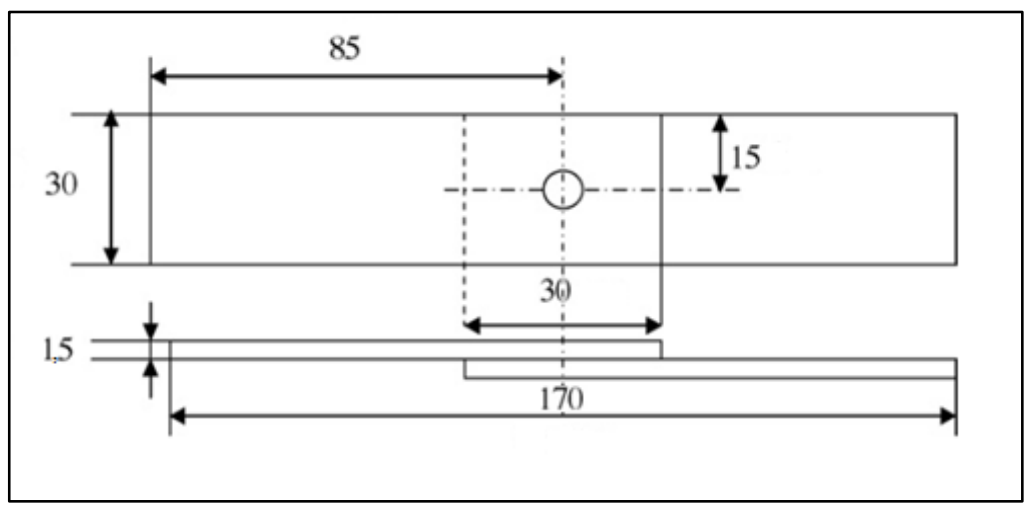

Şekil 1. Kaynak yapılacak numune boyutları ve kaynak sonrası oluşacak boyutlar mm cinsinden gösterimi

Yapıştırıcı paslanmaz çelik sacların 30x30 mm boyutunda ve merkezinde 6-8 $\mathrm{mm}$ çapında boşluk bırakılacak şekilde yüzeye uygulanmıştır. 2-3 saat süresince çelik sac numunelerin üzerine 500 gr ağırlık bırakılarak yapıştırma işlemi gerçekleştirilmiştir. Yapıştırılmış ve yapıştırılmamış olarak çelik sac malzemeler kaynak işlemine hazırlanmıştır. Malzemelerin elektrik direnç nokta kaynağ ile birleştirilmeleri için 150 kVA gücünde AC Punta/Projeksiyon tipinde bir elektrik direnç nokta kaynak makinesi kullanılmıştır. Bu makinenin özellikleri Tablo 2'de verilmiştir.

Tablo 2. Kullanılan direnç nokta kaynak makinesinin özellikleri

\begin{tabular}{cc} 
Makine Gücü & $150 \mathrm{kVA}$ \\
\hline Max Primer Akımı & $280 \mathrm{Amper}$ \\
\hline Primer Kablosu & $120 \mathrm{~mm}^{2}$ \\
\hline Max Kısa Akım Kesme & $34000 \mathrm{kA}$ \\
\hline Elektrot Çapı & Kesik konik uçlu, uç çapı $6 \mathrm{~mm}$ \\
\hline Elektrotlar Arası Mesafe & $25 \mathrm{~mm}$ \\
\hline Elektrot Malzemesi & Kesik konik uçlu ticari saflıkta Cu (Bakır)
\end{tabular}

Deneylerde kullanılan elektrotlar kesik konik uçlu ve çapı $6 \mathrm{~mm}$ olan düz ve silindirik bakır elektrotlar kullanılmıştır. İlk olarak, numunelerin birleştirilmesi için farklı periyotlarda kaynak deneyi yapılmıştır. $\mathrm{Bu}$ deneyler sonucunda kaynak parametreleri hesaplanmıştır. Bu parametreler kaynak akımı ve kaynak zamanıdır. Bu durum gerçekleşirse kaynak çekirdeği sınırları aşılmaktadır. Ön deneyler sonucunda ve literatür 1şı̆ı̆nda elektrot baskı kuvveti $6 \mathrm{kN}$ olarak belirlenmiştir. Kaynak akımı olarak ise 5, 8, 11, kA ve kaynak zamanı olarak 10, 20, 30 periyotun $(1$ periyot $=0.02 \mathrm{sn})$ kararlaştırılmıştır. Deney esnasında kullanılan kaynak parametreleri Tablo 3 'te verilmiştir.

Tablo 3. Birleştirme işleminde kullanılan kaynak parametreleri

\begin{tabular}{ccccc}
$\begin{array}{c}\text { Elektrot } \\
\text { Kuvveti } \\
(\mathbf{k N})\end{array}$ & $\begin{array}{c}\text { Kaynak } \\
\text { Akımı } \\
(\mathbf{A})\end{array}$ & $\begin{array}{c}\text { Sıkışırma süresi } \\
\text { (Periyot) }\end{array}$ & $\begin{array}{c}\text { Kaynak süresi } \\
\text { (Periyot) }\end{array}$ & $\begin{array}{c}\text { Tutma süresi } \\
\text { (Periyot) }\end{array}$ \\
\hline \multirow{2}{*}{6} & 5 & \multirow{2}{*}{20} & $\frac{10}{20}$ & \multirow{2}{*}{20} \\
\cline { 2 - 2 } & 8 & & $\frac{20}{30}$
\end{tabular}




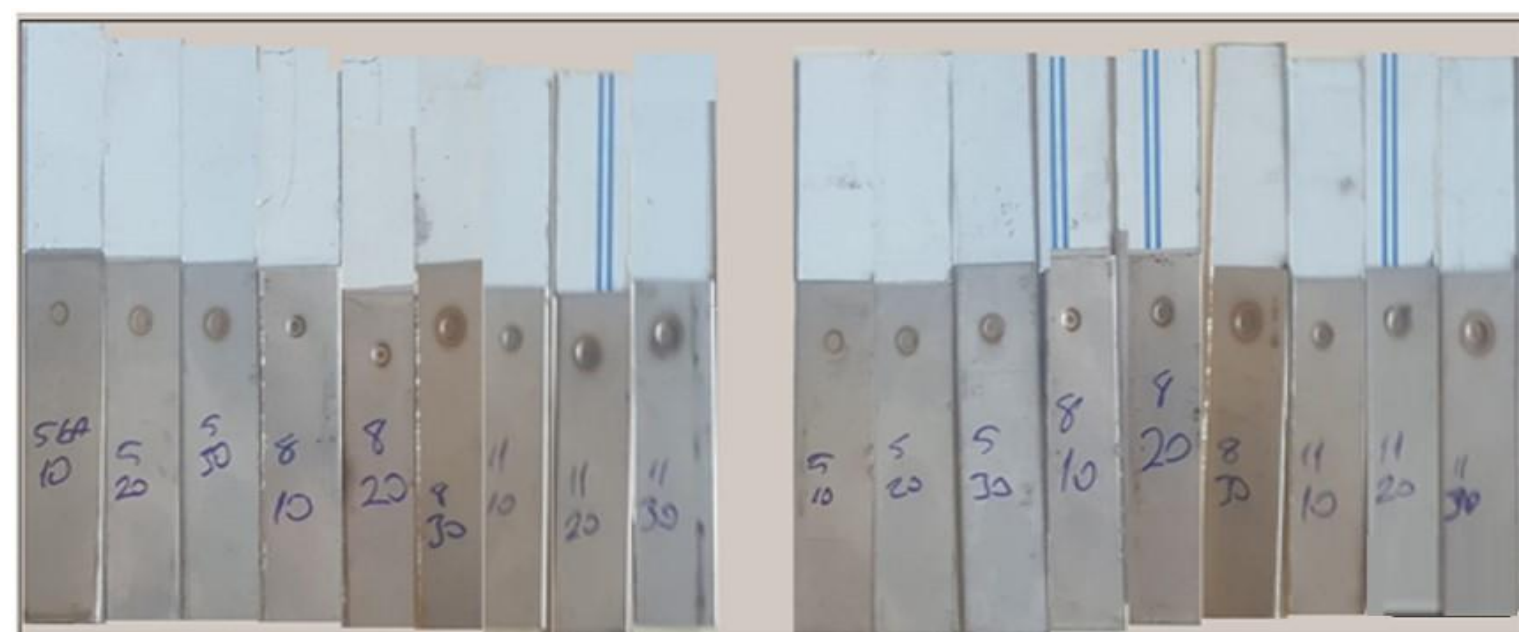

Şekil 2. Kaynă̆l yapılan numuneler

Şekil 2'de kaynağ1 yapılan numuneler gösterilmiştir. Elektrik direnç nokta kaynağ 1 ile birleştirilen kaynaklı parçalar, mekanik özelliklerin tespiti için laboratuvar koşullarında çekme-makaslama deneyine tabi tutulmuşlardır. Tüm numunelere $2 \mathrm{~mm} / \mathrm{dk}$ sabit hızda çekme deneyleri yapılmıştır. Bulunan değerler cihazın gösterdiği en yüksek değerlerdir. Her bir parametreden 3 adet toplamda 54 adet parçaya uygulanmış ve grafikler bu sonuçların aritmetik ortalaması alınarak oluşturulmuştur.

Yapıştırııılı ve yapıştırıcısız olarak kaynaklanan numunelere kaynak akımının etkisini incelemek amacıyla tüm numunelerin kaynak çekirdeklerinin çapları ve derinlikleri dijital kumpas yardımı ile ölçülmüştür. Mikrosertlik deneyleri, ITAB ve kaynak çekirdeği üzerinde sertlik değerlerinin değişimini incelemek için mikroskop yardımı incelenmiş ve deneyler Karabük Üniversitesi Teknoloji Fakültesi Mekanik Testler Laboratuvarında bulunan Vickers sertlik cihazı ile ölçülmüştür. Sertlik ölçümünde 15 sn süre ile 500 gr yük uygulanmış ve $1 \mathrm{~mm}$ aralıklarla izler oluşturularak toplam 15 noktaya test yapılmıştır. Elde edilen veriler ışığında, kaynak akımı ve kaynak zamanının sertlik değerlerine etkilerini grafikler çizilerek incelenmiştir.

Kaynak parametrelerinin ve yapış̧ırıcının tane morfolojisindeki etkilerinin belirlenmesi için optik mikroskop çalışmaları Karabük Üniversitesi Demir Çelik Enstitüsü Metalografi Laboratuvarında gerçekleştirilmiştir. Kullanılan metalografik deney numuneleri 5, 8, 11 kA akım şiddetinde 20 kaynak zamanında birleştirilen yapıştırıcılı ve yapıştırıcısız toplam 6 numunenin incelemesi yapılmıştır. Numuneler hazırlanırken kaynak çekirdeğinin ortasından kesilmiş ve bakalite alınmıştır. Daha sonra yüzey kalitesi artırmak için zımparalama ve parlatma işlemleri yapıllmıştır. Parlatılan numunelere \%2'lik Nital ve elektrolitik dağlayıcı okzalik asit ile dağlama işlemi yapılmıştır.

\section{BULGULAR VE TARTIȘMA}

\section{A. ÇEKME-MAKASLAMA DENEYI SONUÇLARI}

Çalışmada; her bir parametrede 3 adet olmak üzere toplam 54 parçaya çekme-makaslama deneyi uygulanmıştır. Sonuçlar bulunan bu 3 değerlerin ortalaması alınarak elde edilmiştir. Yapıştırıcılı ve yapıştırıcısız kaynak bağlantılarına ait çekme-makaslama deney sonuçları Tablo 4 ve 5'te verilmiştir. 
Tablo 4. Yapıştırıcısız kaynak numunelerinin çekme-makaslama deney sonuçları

\begin{tabular}{|c|c|c|c|c|c|c|}
\hline \multirow{2}{*}{$\begin{array}{c}\text { Elektrot } \\
\text { Kuvveti } \\
(\mathbf{k N})\end{array}$} & \multirow{2}{*}{$\begin{array}{c}\text { Kaynak } \\
\text { Zamanı } \\
\text { (Periyot) }\end{array}$} & \multirow{2}{*}{$\begin{array}{c}\text { Kaynak } \\
\text { Akımı } \\
(\mathbf{k A})\end{array}$} & \multicolumn{4}{|c|}{$\begin{array}{c}\text { Çekme-Makaslama Dayanımı } \\
\text { (daN) }\end{array}$} \\
\hline & & & 1.Numune & 2.Numune & 3.Numune & Ortalama \\
\hline \multirow{9}{*}{$6 \mathrm{kN}$} & \multirow{3}{*}{10} & 5 & 697 & 638 & 652 & 662 \\
\hline & & 8 & 960 & 971 & 986 & 972 \\
\hline & & 11 & 1189 & 1101 & 1162 & 1150 \\
\hline & \multirow{3}{*}{20} & 5 & 805 & 778 & 792 & 791 \\
\hline & & 8 & 981 & 1006 & 1001 & 996 \\
\hline & & 11 & 1085 & 1105 & 1121 & 1104 \\
\hline & \multirow{3}{*}{30} & 5 & 849 & 832 & 860 & 847 \\
\hline & & 8 & 1320 & 1295 & 1153 & 1256 \\
\hline & & 11 & 1258 & 1272 & 1298 & 1276 \\
\hline
\end{tabular}

Tablo 5. Yapıştırıcılı kaynak numunelerinin çekme-makaslama deney sonuçları

\begin{tabular}{|c|c|c|c|c|c|c|}
\hline \multirow{2}{*}{$\begin{array}{c}\text { Elektrot } \\
\text { Kuvveti } \\
(\mathbf{k N})\end{array}$} & \multirow{2}{*}{$\begin{array}{c}\text { Kaynak } \\
\text { Zamanı } \\
\text { (Periyot) }\end{array}$} & \multirow{2}{*}{$\begin{array}{c}\text { Kaynak } \\
\text { Akımı } \\
(\mathbf{k A})\end{array}$} & \multicolumn{4}{|c|}{$\begin{array}{c}\text { Çekme-Makaslama Dayanımı } \\
\text { (daN) }\end{array}$} \\
\hline & & & 1.Numune & 2.Numune & 3.Numune & Ortalama \\
\hline \multirow{9}{*}{$6 \mathrm{kN}$} & \multirow{3}{*}{10} & 5 & 742 & 682 & 713 & 712 \\
\hline & & 8 & 1023 & 1041 & 1028 & 1030 \\
\hline & & 11 & 1235 & 1173 & 1223 & 1210 \\
\hline & \multirow{3}{*}{20} & 5 & 854 & 881 & 848 & 861 \\
\hline & & 8 & 1044 & 1051 & 1084 & 1059 \\
\hline & & 11 & 1158 & 1182 & 1211 & 1183 \\
\hline & \multirow{3}{*}{30} & 5 & 886 & 867 & 903 & 885 \\
\hline & & 8 & 1373 & 1327 & 1203 & 1301 \\
\hline & & 11 & 1302 & 1315 & 1357 & 1324 \\
\hline
\end{tabular}

Tablo 4 ve 5 genel olarak incelendiğinde kaynak akımının artması sonucunda çekme-makaslama dayanımının buna paralel olarak artması gözlemlenmiştir. Ayrıca tüm yapıştırıcılı numunelerin yapıştırıcısız numunelere göre çekme-makaslama dayanımında ilave yapıştırıcıdan dolayı ortalama 50$70 \mathrm{daN}$ artış tespit edilmiştir. Yapıştırııılı ve yapıştırıcısız kaynak bağlantılarının her ikisinde de $5 \mathrm{kA}$ düşük kaynak akım şiddetinde kaynak çekirdek kesiti küçük boyutlu olduğundan dolayı düşük mukavemet değerleri elde edilmekte ve kopma olayı yaşanmaktadır. Tablo 4 ve 5 'te görüldüğü üzere en düşük çekme-makaslama dayanımları $5 \mathrm{kA}$ kaynak akım şiddetinde kaynaklanan numunelerde görülmektedir. $11 \mathrm{kA}$ kaynak akımında bağlantısı yapılan numunelerde ise kaynak çekirdek kesitinin diğer akım şiddetlerine göre boyutu daha büyük olduğundan dayanımları daha fazladır ve kopma olayı düğmelenme tarzında oluşmaktadır.

\section{A. 1. Çekme-Makaslama Dayanımına Kaynak Akım Şiddetinin ve Kaynak Zamanının Etkisi}

Şekil 3'te yapıştırıcılı ve yapıştırıcısız kaynak bağlantısı yapılan östenitik-ferritik paslanmaz çeliklerin 10,20 ve 30 periyot kaynak süresinde $5,8,11 \mathrm{kA}$ kaynak akım şiddetinde çekme-makaslama dayanımları grafik olarak verilmiştir. 

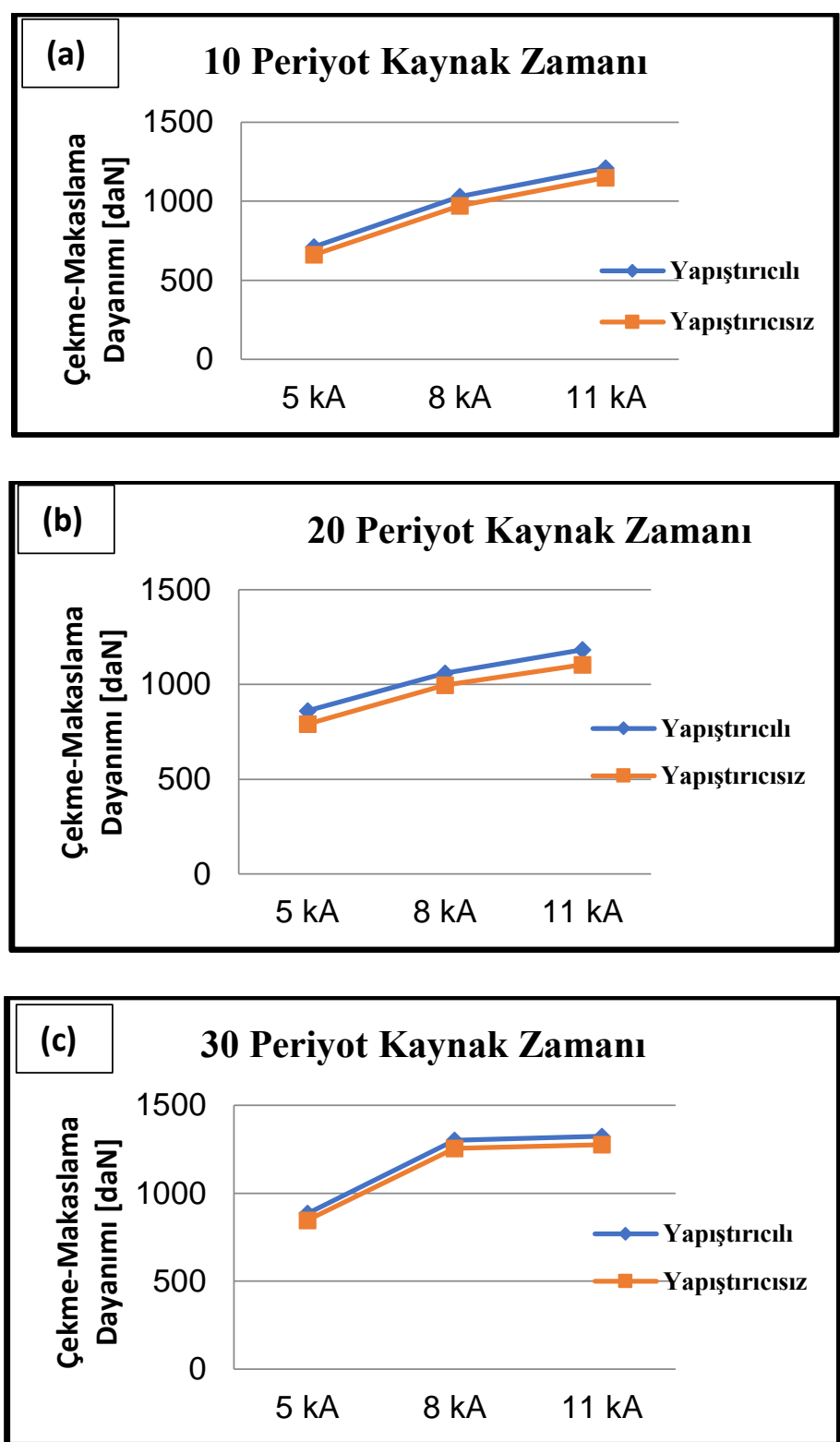

Şekil 3. Yapıştırıcılı ve yapıştırıcısız kaynak bağlantılarının a) 10 periyot, b) 20 periyot ve c) 30 periyot kaynak süresinde kaynak akım șiddetinin çekme-makaslama dayanımına etkisi

\section{A. 2. Çekme-Makaslama Dayanımlarının Birbirleri ile Karşılaştırılması}

Şekil 4'te yapıştırıcılı ve yapıştırıcısız kaynak bağlantısı yapılan östenitik-ferritik paslanmaz çeliklerin 10,20 ve 30 periyot kaynak zamanlarında $5,8,11 \mathrm{kA}$ kaynak akım şiddetinde çekme-makaslama dayanımlarının karşılaştırılması grafik olarak verilmiştir. Yaptıkları çalışmada Hayat, Hasanbaşoğlu ve Gülbahar, artan kaynak zamanının ısı girdisi üzerinde, akım şiddeti artışı gibi etki göstererek, benzer ve farklı malzeme çiftlerinin direnç nokta kaynaklı birleştirmelerin dayanımlarını arttırdığını bildirmişlerdir [26-28]. 

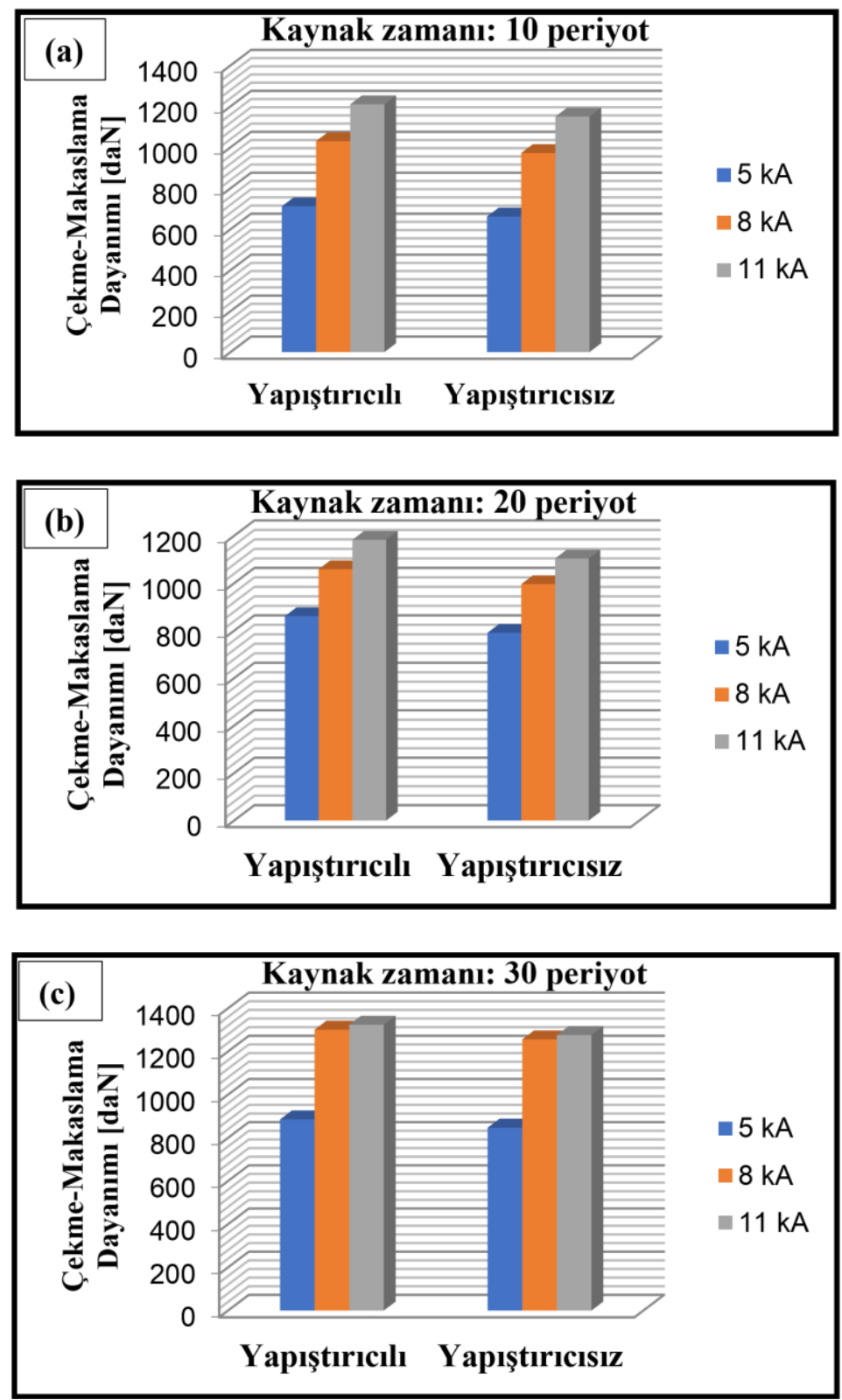

Şekil 4. Yapıștırıcıll ve yapıştırıcısız kaynak bağlantılarının (a) 10 periyot, (b) 20 periyot ve (c) 30 periyot kaynak zamanında çekme-makaslama dayanımlarının karşılaş̧ırılması

Şekil 4'teki grafiklere bakıldığında kaynak akımının ve kaynak şiddetinin artması sonucunda buna paralel olarak çekme-makaslama dayanımının paslanmaz çelik malzemelerde arttı̆̆ saptanmıştır. Yapıştırıcı olarak kaynatılan numunelerde yapıştırıcısız kaynak bağlantısı yapılan numunelere göre maksimum çekme-makaslama dayanımında artış gözlemlenmiştir. Literatürde yaptıkları çalışmalarda Kocabekir, Vural ve Hayat benzer şekilde, artan kaynak zamanına bağlı olarak, birleştirmelerin çekmemakaslama dayanımlarının arttığını bildirmişlerdir [23,29,30].

\section{A. 3. Kaynak Numunelerinin Çekme-Makaslama Deneyi Sonucu Meydana Gelen Kopma Tipleri}

Kaynak bağlantısı yapılan yapıştırıcılı ve yapıştırıcısız numunelerin çekme-makaslama deneyi sonucunda kaynak akımı ve kaynak zamanının kopma türüne etkisi ve kriterlere uygun olup olmadığ incelenmiştir. Çekme-makaslama deneyi sonucunda kopma görüntüleri incelendiğinde yapıştırıcılı ve yapıştırıcısız numunelerin tümünde kopma ITAB bölgesinin tane irileşmesinin olduğu yerden 
başlayarak meydana geldiği görülmüştür. Kaynaklı bağlantılarda düğme ve ayrılma şeklinde iki tip kopma görülmüştür. Düşük kaynak akımı ve 1sı girdisine bağlı olarak oluşan, kaynak çekirdek çapının ve kaynak bölgesinin yetersiz kaldığı kopma türü ayrılma kopma tipidir. Şekil 5 'te $5 \mathrm{kA}, 8 \mathrm{kA}$ ve $11 \mathrm{kA}$ kaynak akımında çekme-makaslama deneyi sonucu oluşan ayrılma tipi kopma görüntüsü verilmiştir. Kaynak zamanı artışı ile ısı girdisinde artışa sebep olan ve buna paralel olarak kaynak çekirdek çapı ve kaynak bölgesinde artış görülen, bu nedenle kaynak bağlantı dayanımında yükselme görülen kopma tipi düğme türü kopma tipidir. Ayrıca bu tip kopma tipi kaynak parametrelerinin uygun olduğunu gösterir.

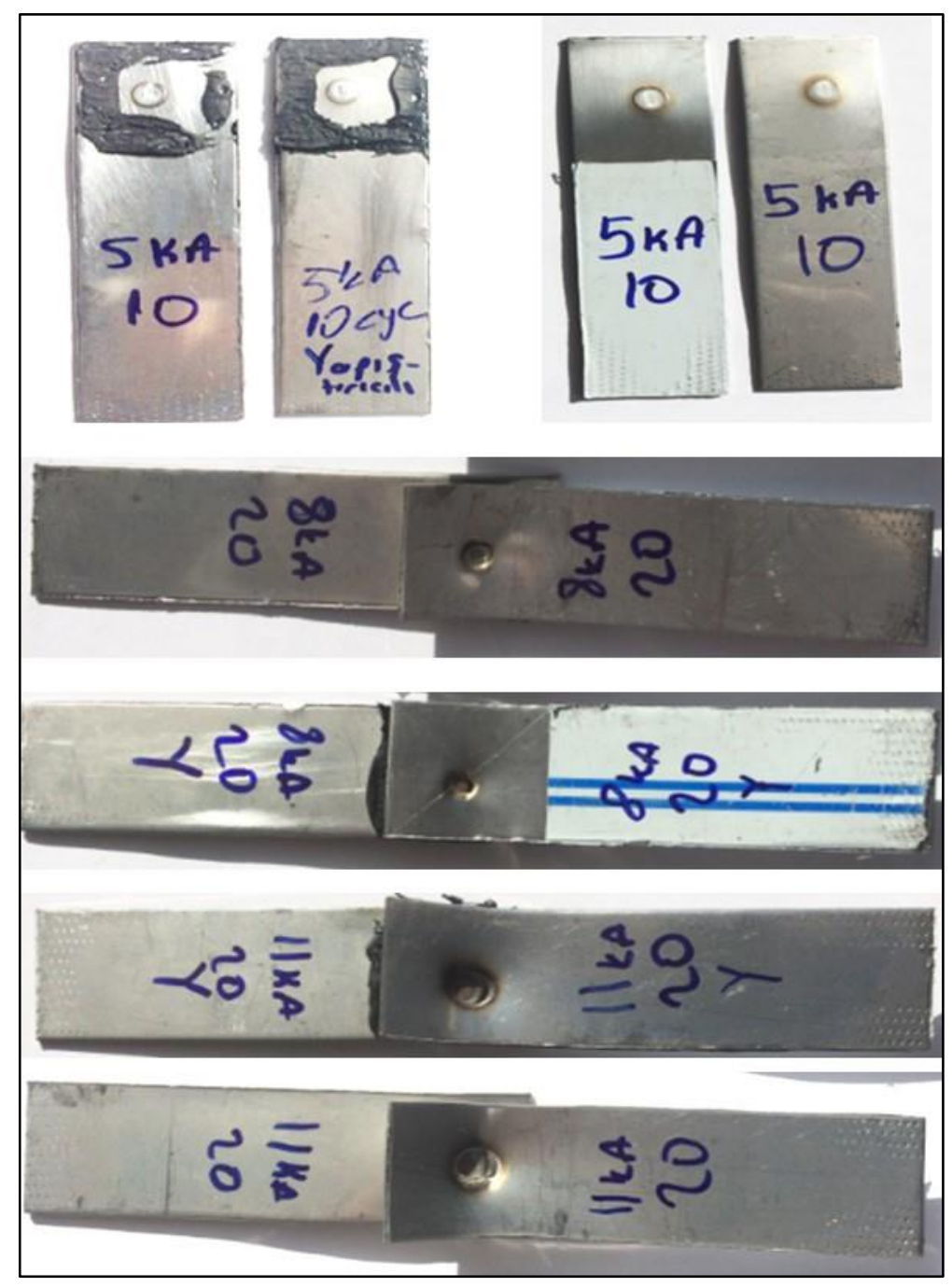

Şekil 5. 5, 8 ve 11 kA kaynak akımında yapıştırıcılı ve yapıştırıcısız düğme tipi kopma görüntüleri

Çekme-makaslama deney sonucunda, kaynak bağlantısının kopma şekli ITAB' dan başlayıp malzemeye doğru yırtılma biçiminde oluşur. Bunun nedeni çekirdek bölgesinin çekme-makaslama dayanım değeri ana malzemenin dayanım değerinden daha fazla olmasıdır.

\section{B. KAYNAK NUMUNELERININ KAYNAK ÇEKİRDEĞİ ÇAPI VE DERINLİĞİ ÖLÇÜM SONUÇLARI}

Yapıştırıcılı ve yapıştırıcısız kaynak bağlantısı yapılan numunelerde kaynak periyot zamanı kısaldıkça çekirdek çapı küçülür, bunun aksine kaynak periyot zamanı arttıkça ergiyen bölgenin dışarı çıkması sebebiyle çekirdek çapının arttığı görülmüştür. Buna göre en büyük kaynak çekirdek çapı; 11 kA kaynak akım şiddetinde 30 periyot kaynak zamanında bağlantısı yapılan yapıştırıcılı numunede $7.2 \mathrm{~mm}$ ve çekirdek derinliğinin 1,2 mm olarak ölçülmüştür. En küçük kaynak çekirdek çapı ise; 5 kA kaynak akım 
şiddetinde 10 periyot kaynak zamanında bağlantısı yapılan yapıştırıcısız numunede $5.1 \mathrm{~mm}$ ve çekirdek derinliği $0,25 \mathrm{~mm}$ olarak ölçülmüştür.

Şekil 6-9'da yapıştırıcılı ve yapıştırıcısız kaynak numunelerine, kaynak zamanının ve kaynak akım şiddetinin çekirdek çapına ve derinliğine etkisi verilmiştir. Grafikler incelendiğinde, kaynak akım şiddeti ve kaynak zamanı arttıkça kaynak çekirdek çapının ve derinliğinin de arttığı görülmektedir.

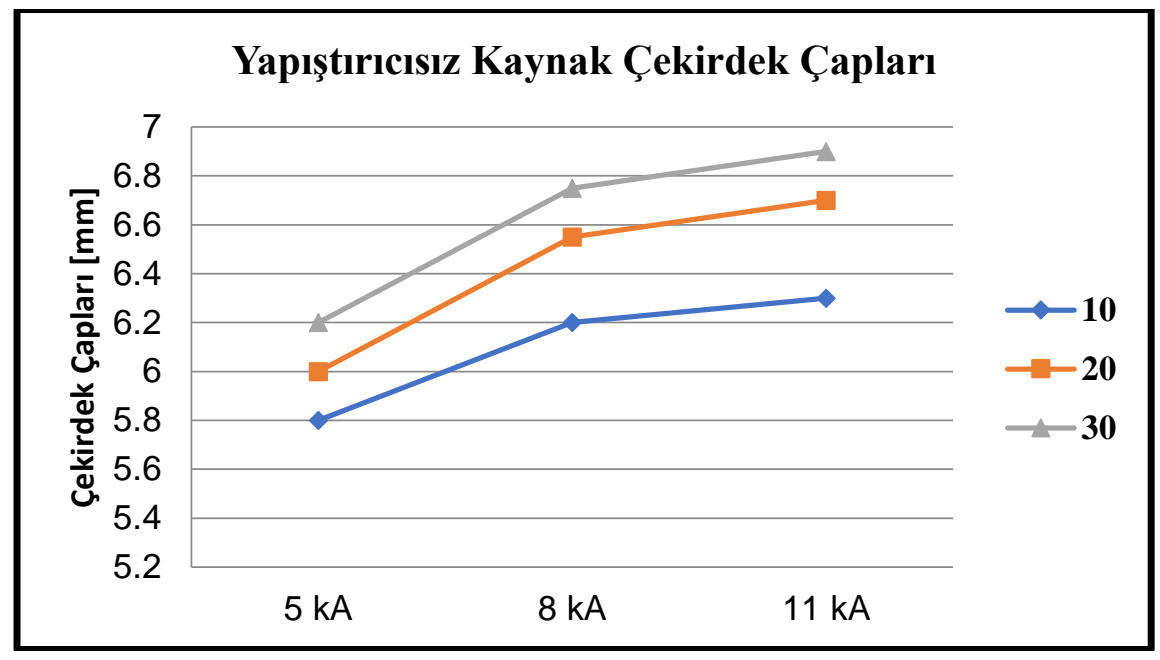

Şekil 6. Yapıştırıcısız kaynak numunelerinin kaynak çekirdek çapına kaynak akım şiddeti ve kaynak periyot zamanının etkisi

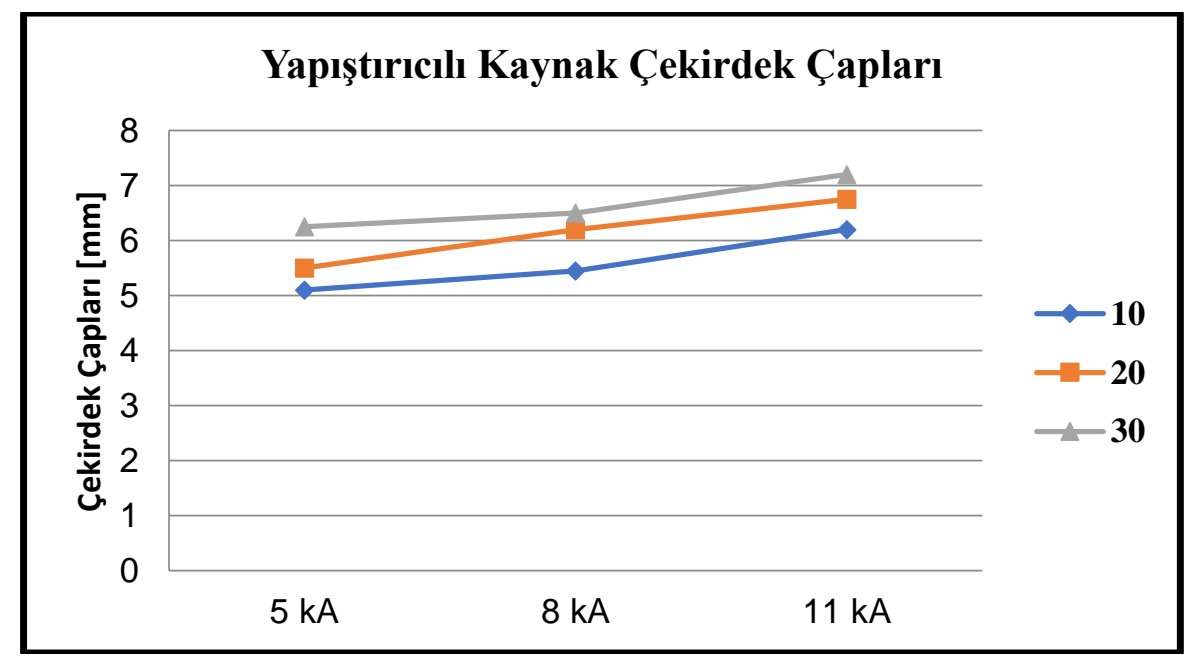

Şekil 7. Yapıștırıcıl kaynak numunelerinin kaynak çekirdek çapına kaynak akım şiddeti ve kaynak periyot zamanının etkisi 


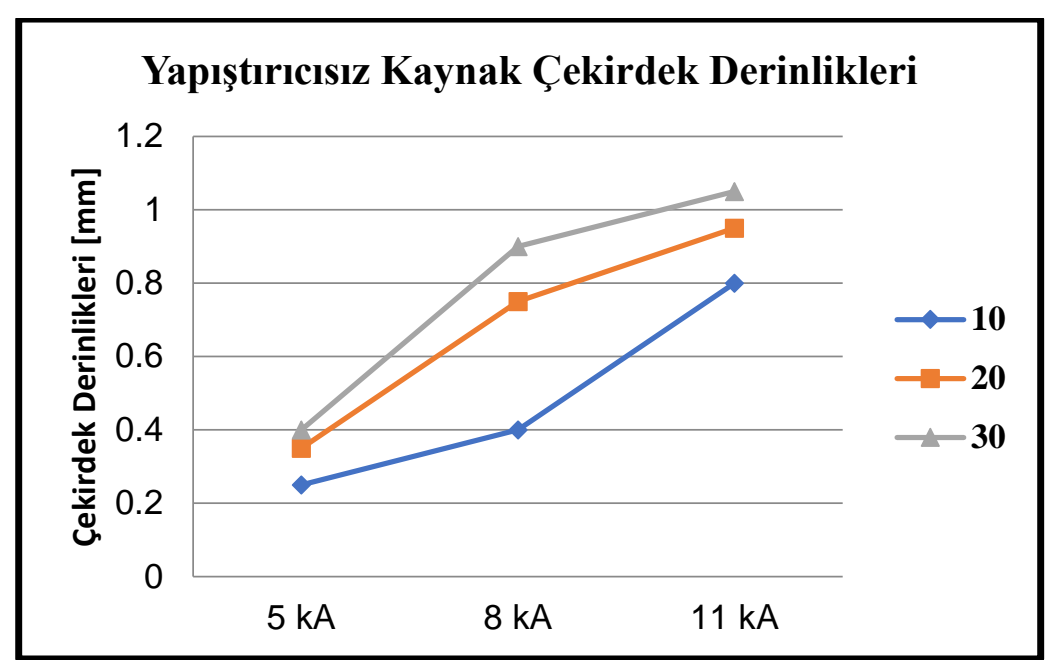

Şekil 8. Yapıştırıcısız kaynak numunelerinin kaynak çekirdek derinliğine kaynak akım şiddeti ve kaynak periyot zamanının etkisi

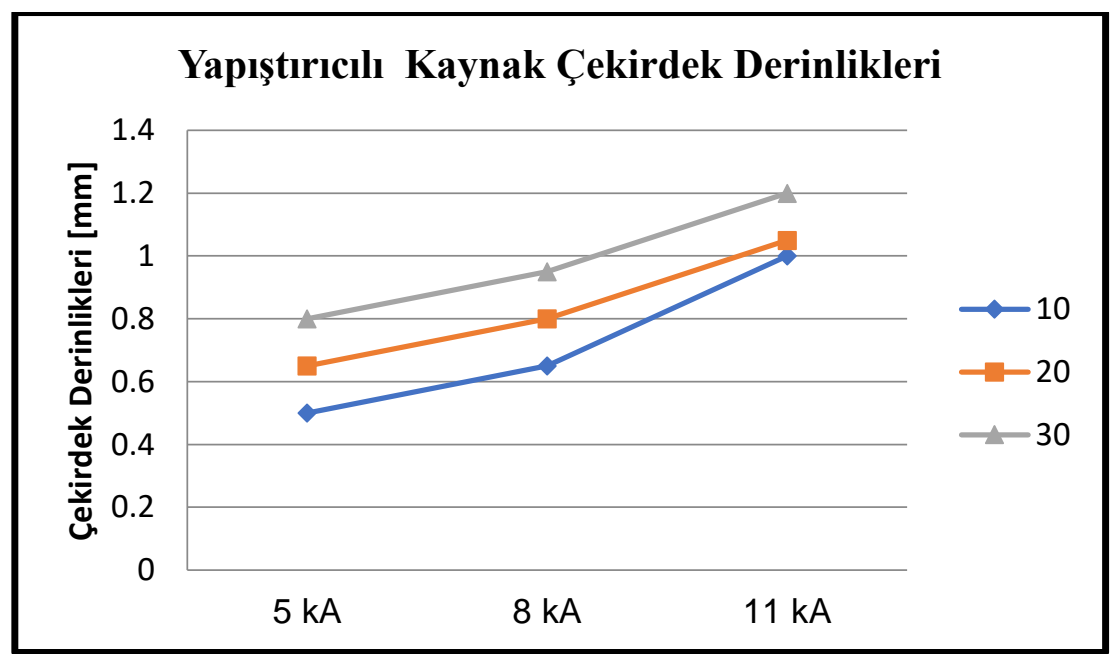

Şekil 9. Yapıştırıcılı kaynak numunelerinin kaynak çekirdek derinliğine kaynak akım şiddeti ve kaynak periyot zamanının etkisi

\section{SERTLİK DENEYİ SONUÇLARI}

Yapıştırıcılı ve yapıştırıcısız olarak 5, 8, 11 kA kaynak akımında ve 20 periyot kaynak zamanında birleştirilen kaynaklı bağlantıların mikroyapıları için hazırlanan numunelere sertlik testleri uygulanmıştır. Bu testler; ana malzeme, ITAB ve kaynak çekirdeğindeki sertlik değişimini belirlemek amacıyla 6 adet numuneye uygulanmıştır. Uygulanma biçimi Şekil 10'de gösterilmiştir. Bu deneyden elde edilen veriler grafikler ile Şekil 11 ve 12 'de verilmiştir.

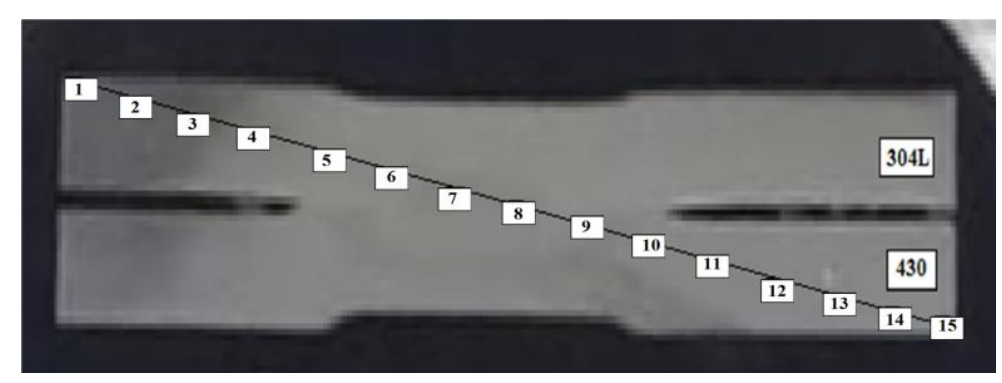

Şekil 10. Sertlik ölçüm noktaları 


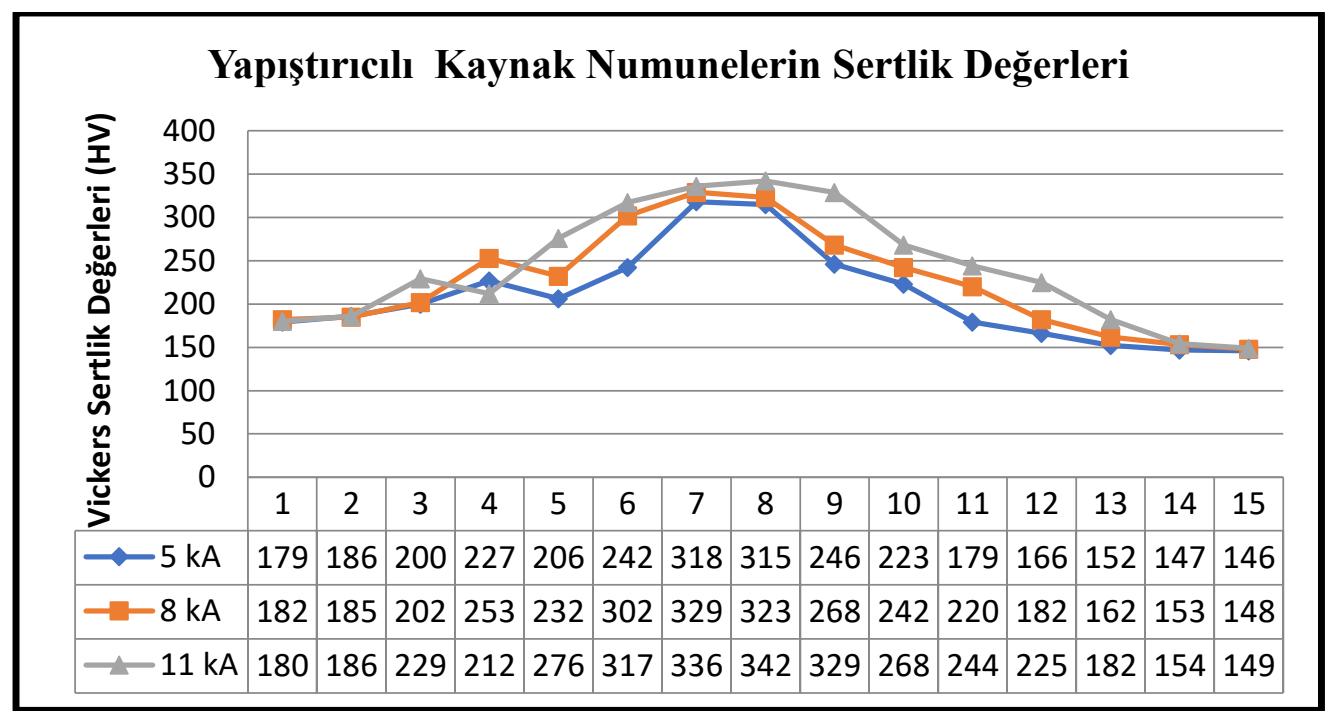

Şekil 11. 20 periyot kaynak zamanında yapıştırıcılı olarak birleştirilmiş kaynak numunelerinin sertlik değerleri

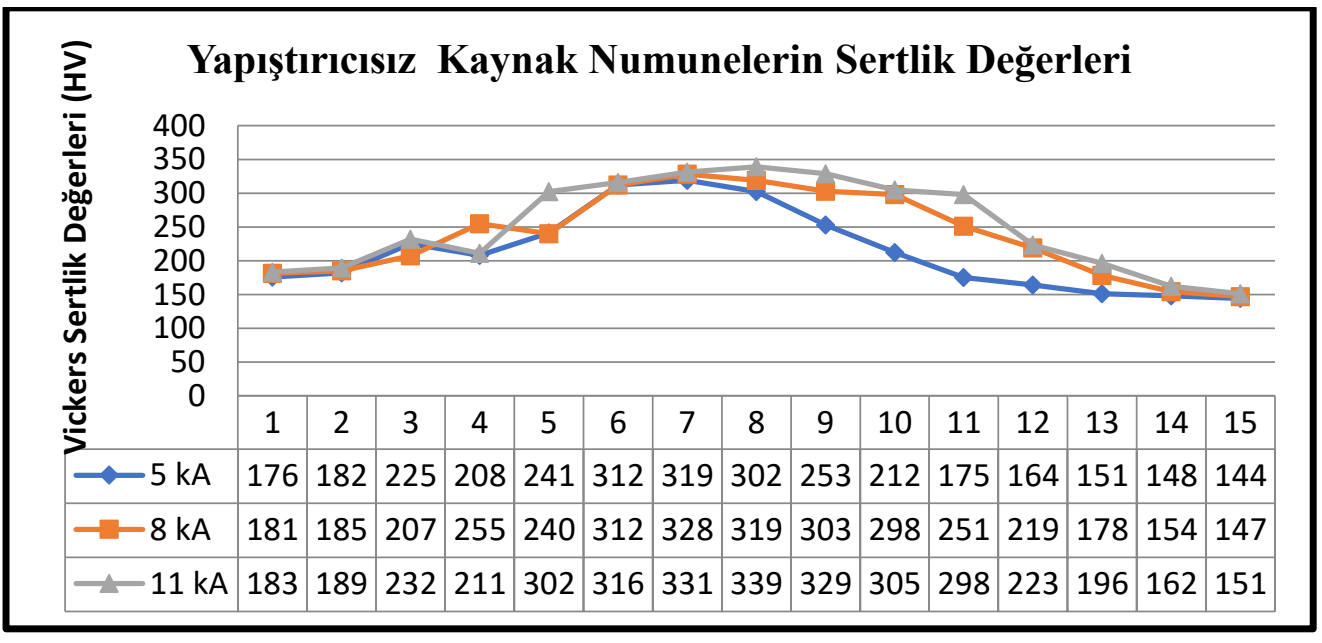

Şekil 12. 20 periyot kaynak zamanında yapıştırıcısız olarak birleştirilmiş kaynak numunelerinin sertlik değerleri

Verilen grafikler incelendiğinde; kaynak çekirdeğinden ana metale doğru sertlik değerleri düştüğü görülmektedir. En yüksek sertlik değeri kaynak çekirdeğinden ölçülmüştür ve hemen peşinden ITAB ve ana metal gelmektedir. Grafikler genel olarak incelendiğinde; kaynak çekirdeğinden esas metale doğru sertlikte bir düşüş olduğu görülmektedir. Tablo 6'da yapıştırıcılı ve yapıştırıcısız kaynak numunelerden elde edilen verilerin en düşük ve en yüksek sertlik değerlerine göre karşılaştırılması verilmiştir.

Tablo 6. Numunelerin tümünün en düşük ve en yüksek sertlik değerlerinin karşılaştırılması.

Sertlik Değerleri [HV]

\begin{tabular}{ccccccc}
\hline \multirow{2}{*}{ Kaynak Çifti } & \multicolumn{2}{c}{ Ana Malzeme } & \multicolumn{2}{c}{ ITAB } & \multicolumn{2}{c}{ Kaynak Çekirdeği } \\
\cline { 2 - 6 } & En Yüksek & En Düşük & En Yüksek & En Düşük & En Yüksek & En Düşük \\
\hline $\begin{array}{c}\text { Yap1ştırıcıl1 } \\
(304 L+430)\end{array}$ & $186 / 162$ & $179 / 146$ & $276 / 268$ & $200 / 182$ & 342 & 302 \\
\hline $\begin{array}{c}\text { Yapıştırıc1s1Z } \\
(304 L+430)\end{array}$ & $189 / 154$ & $176 / 144$ & $255 / 251$ & $207 / 196$ & 339 & 298
\end{tabular}


Yapıştırıılı ve yapıştırıcısız yapılan kaynaklı bağlantıların kaynak akımı ve kaynak zamanının artması sebebiyle sertlik değişimi sonuçları üzerinde artırıcı yönde bir etki gözlemlenmiştir. Ayrıca numunelerin kaynak bölgelerinden ölçülen sertlik değerleri ana malzeme ve ITAB' dan daha yüksek olduğu, kaynak akım şiddetinin ve kaynak zamanının artmasıyla sertlik değerlerinin arttığı tespit edilmiştir. Buradan, elektrik direnç nokta kaynak esnasında malzemeye verilen yüksek 1sı girdisi kaynak bölgesinde daha uzun süre kalmakta ve bunun sonucunda kaynak bölgesinin sertlik değerlerinde bir miktar artışa sebep olur sonucu çıkarılabilir. Kaynak bölgesinin boyutu yapıştırıcılı kaynak numunelerinde yapıştırıcısızlara göre daha büyük olduğundan yapıştırıcısız kaynak numunelerin yapıştırıcılara göre bazı sertlik noktalarında daha yüksek sertlik değerleri ortaya çıkmıştır. Bunun sebebi; kaynak bölgelerindeki boyut farklılıkları olarak açıklanabilir. Yapıştırıcısız kaynak numunelerinde yapıştırıcılara göre kaynak bölgesi daha büyük olmasının nedeni; yapıştırıcının kaynak yapılacak bölgeyi daraltarak sınırlandırmasıyla açıklanabilir. Ayrıca kaynak yapılan tüm numunelerde kaynak zamanının artmasıyla 1S1 girdisinde bir artış gözlemlenmekte ve ITAB'daki sertlik değerleri arttıkça ITAB'daki tane irileşmesi arttığı görülmektedir. Martin ve arkadaşları, 304 östenitik paslanmaz çelik sacları direnç nokta kaynak yöntemi ile birleştirmiş ve benzer sonuçları rapor etmişlerdir [30]. Vural vd, galvanizli çelik ile östenitik paslanmaz çelik sacları direnç nokta kaynağı ile birleştirmişler ve mikrosertlik ölçümleri sonucunda en yüksek sertlik değerinin kaynak çekirdeğinin ortasında 350 HV olarak ölçüldüğünü belirtmişlerdir [29]. Hayat vd, (2007), IF çeliklerini direnç nokta kaynak yöntemiyle birleştirmiş ve tüm kaynaklı numunelerde kaynak bölgesinin mikrosertlik değerlerinin ITAB ve ana malzemenin sertlik değerlerinden daha yüksek olduğunu belirtmişlerdir [31].

\section{KAYNAK NUMUNELERINIIN MIKROYAPILARININ İNCELENMESI}

Farklı parametrelerde elektrik direnç nokta kaynak yöntemiyle ilave yapıştırıcılı ve yapıştırıcısız olarak birleştirilen östenitik-ferritik paslanmaz çeliklerin bağlantıları mikroyapı incelemeleri için kaynak çekirdeği kesitlerine 50x ve 200x büyütme uygulanmış ve ITAB ile kaynak çekirdeği bölgelerinin mikroyapı görüntüleri optik mikroskop yardımı ile elde edilmiştir. 5, 8 ve $11 \mathrm{kA}$ akım şiddetinde ve 20 periyot kaynak zamanında elektrik direnç nokta kaynağı ile birleştirilen yapıştırıcılı ve yapıştırıcısız 6 adet numunenin mikroyapı görüntüleri verilmiştir.
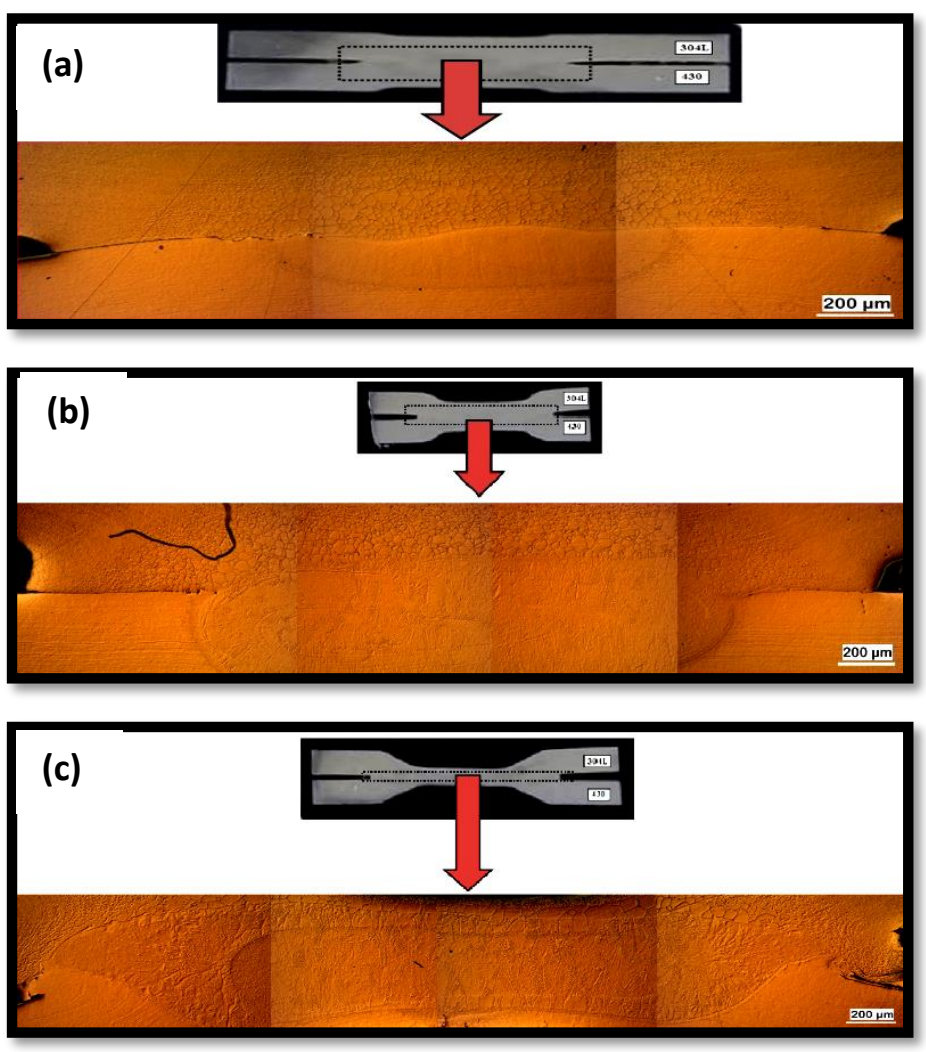

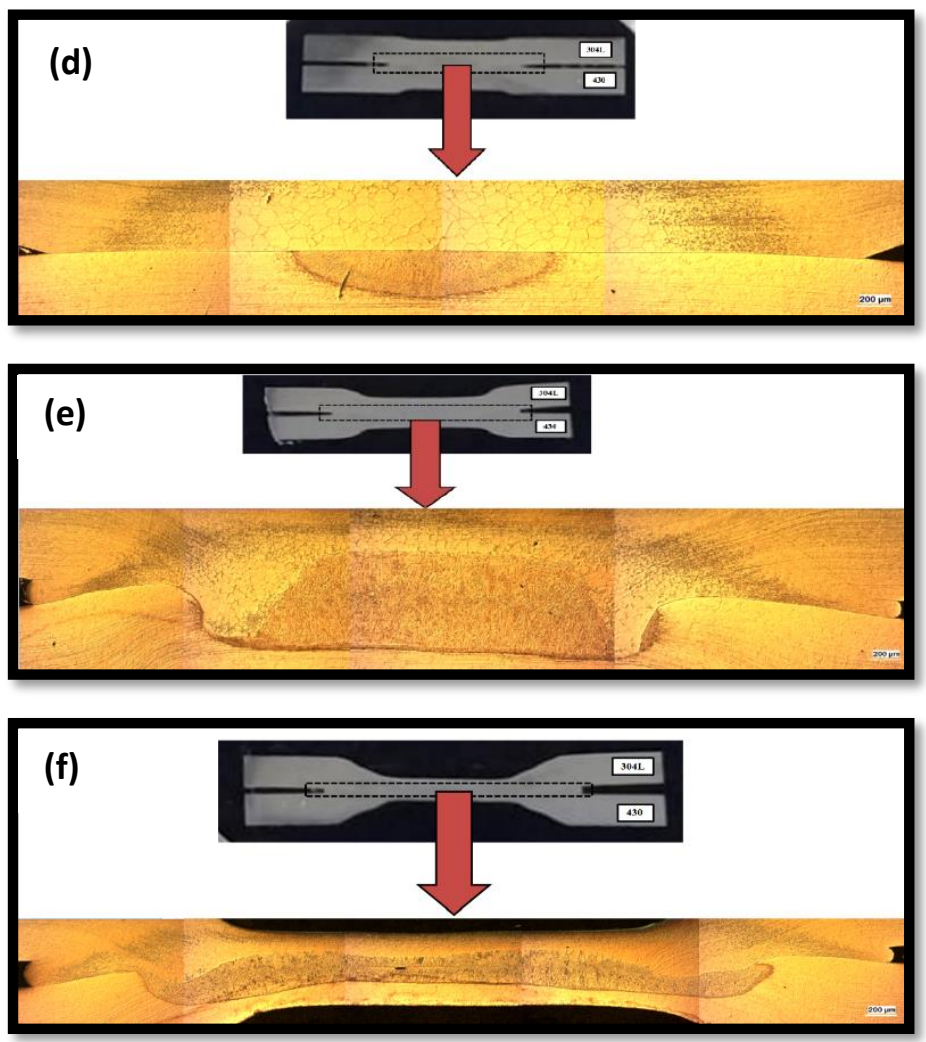

Şekil 15. Farklı kaynak akımında 20 periyot kaynak zamanında yapıştırıcll ve yapıştırısız kaynağl yapılan paslanmaz çeliklerin 200x mikroyapı görüntüsü (a) $5 \mathrm{kA}$ yapıstırıcıll, (b) $8 \mathrm{kA}$ yapıstırıcıll, (c) $11 \mathrm{kA}$

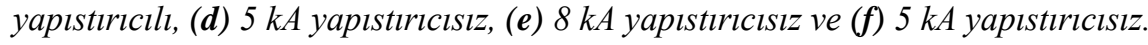

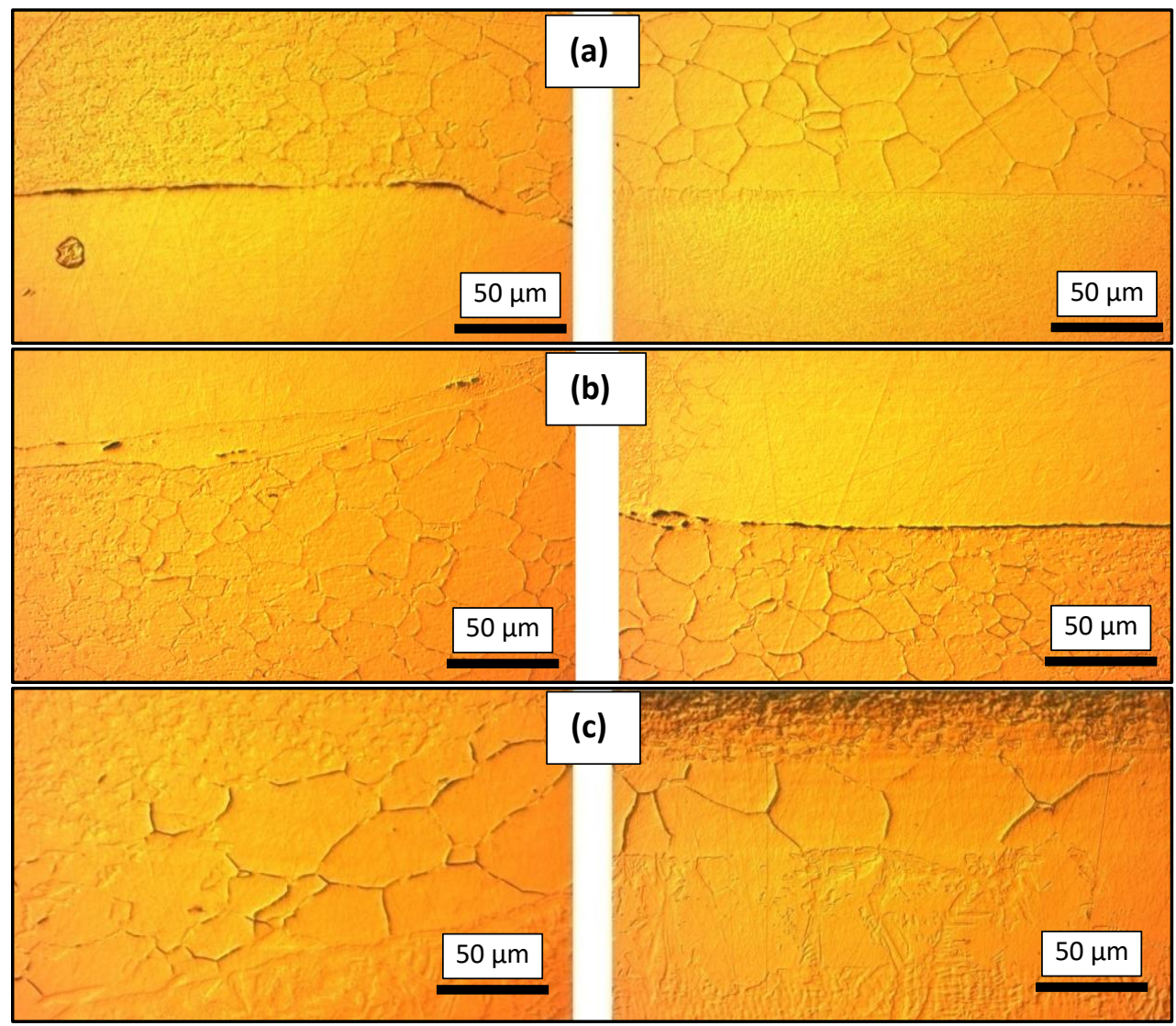




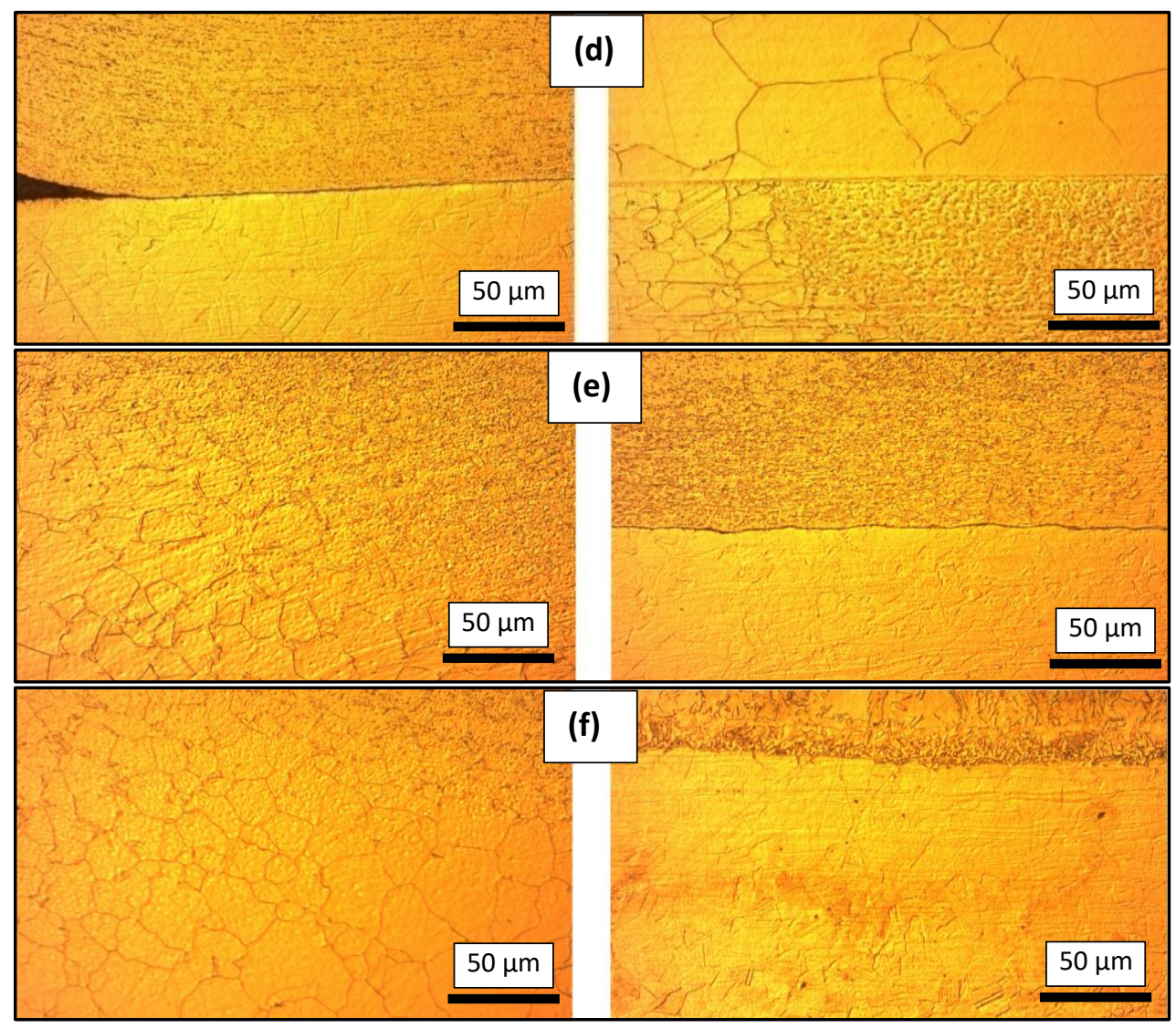

Şekil 16. Farklı kaynak akımında 20 periyot kaynak zamanında kaynă̆ yapılan paslanmaz çeliklerin ITAB ve Çekirdek bölgesi 50x mikroyapı görüntüsü. (a) $5 \mathrm{kA}$ yapıstırıcılı, (b) $8 \mathrm{kA}$ yapıstırıcıll, (c) $11 \mathrm{kA}$ yapıstırıcılı, (d) $5 \mathrm{kA}$ yapıstırıcisız, (e) $8 \mathrm{kA}$ yapıstırıcisız ve (f) $5 \mathrm{kA}$ yapıstırıcisiz.

Elektrik direnç nokta kaynak işlemi yapılan yapıştırıcılı ve yapıştırıcısız tüm numunelerin mikroyapı görüntüleri incelendiğinde kaynak çekirdeğinin mikroyapısının esas malzemeden farklı olduğu görülmektedir. Kaynak çekirdeğine bakıldığında taneler 1s1 merkezine doğru yönelmiştir. Ayrıca uygulanan kaynak işlemi ile ara yüzeyde yeni taneler oluşmuştur. Bu tanelerin orijinal tanelerden daha büyük olduğu görülmüştür.

Ferritik ve östenitik paslanmaz çeliklerin 1sı iletim kabiliyeti düşük olduğundan dolayı kaynak sırasında oluşan 1sı, kaynak bölgesinde daha fazla süre kalmaktadır. Bu sürenin uzaması tanelerin daha fazla irileşmesine sebep olmaktadır. Yapıştırıcılı ve yapıştırıcısız olarak kaynaklanan numunelerin tüm mikroyapı görüntüleri incelendiğinde genel olarak kaynak akımının ve kaynak zamanının artması ile tanelerin irileştiği görülmüş̧ür. Bu irileşmenin sebebi artan 1S1 girdisidir. Artan 1S1 girdisine paralel olarak kaynak çekirdek genişliğinin ve derinliğinin arttı̆̆ görülmüştür. Literatürdeki yapılan çalışmalarda kaynak zamanı artı̧̧ına bağlı olarak, kaynak akımı artışıyla ısı girdisinde artış tespit etmişler ve artan 1S1 girdisinin etkisiyle, birleştirmelerde tane büyümesi olduğunu bildirmişlerdir $[31,32]$.

\section{SONUC}

Bu çalışmada, AISI 304L ve AISI 430 tip paslanmaz çeliklerin Tereson MS 9220 ilave yapıştırıcı kullanılarak elektrik direnç kaynağında birleştirilmiştir. Paslanmaz çeliklerin nokta direnç kaynak kabiliyetlerine ilave yapıştırıcıların etkisinin araştırıldı̆̆ bu çalışmanın sonucunda; 
1. Farklı parametreler uygulanarak yapıştırıcılı ve yapıştırıcısız olarak gerçekleşen elektrik nokta direnç kaynağ yöntemiyle tüm malzemelerde birleştirme sağlanmıştır.

2. Çekme-makaslama deney sonuçları incelendiğinde kaynak zamanı ve kaynak akımı arttıkça buna paralel olarak çekme-makaslama dayanımının arttığı görülmüştür.

3. Kaynak zamanı ve kaynak akımının artması sonucunda 1sı girdisi artmış ve buna paralel olarak çekirdeğin çapının ve çekirdek derinliğinin arttı̆̆ı gözlemlenmiştir.

4. Sertlik testleri sonucunda en yüksek sertlik değerleri kaynak çekirdeğinde ölçülmüş ve sırasıyla ITAB ve ana malzeme hemen arkasından gelmiştir.

5. Mikroyapı görüntülerine bakıldı̆̆ında, kaynak süresince uygulanan akımın süresi ve şiddeti arttıkça kaynak bölgelerinde kalınlık azalmıştır.

6. Mikroyapı görüntüleri incelendiğinde genel olarak tüm numunelerde östenitik kısımlarda kaynak akımının ve kaynak zamanının artması sonucunda yeni taneler oluşmuş ve bu tanelerin yapıların irileştiği tespit edilmiştir.

7. Yapıştırıcı yapılan kaynak numunelerin yapıştırıcısızlara göre tüm kaynak parametrelerinde kaynak çekirdek bölgesinde yapıştırıcıdan dolayı bir daralma meydana geldiği tespit edilmiştir.

8. Yapıştırıcılı yapılan kaynak numunelerin yapıştırıcısızlara göre çekme-makaslama dayanım değerleri karşılaştığında genel olarak tüm numunelerde 50 ila 100 daN arasında artış tespit edilmiştir.

TEȘEKKÜR: Bu çalışma Karabük Üniversitesi Bilimsel Araştırma Projeleri Koordinasyon Birimi tarafından desteklenmiştir. Proje Numarası: KBUBAP-18-YL-109.

\section{KAYNAKLAR}

[1] P. R. Spena, A. Angelastro, G. Casalino, "Hybrid laser arc welding of dissimilar TWIP and DP high strength steel weld," Journal of Manufacturing Processes, c. 39, ss. 233-240, 2019.

[2] A. Angelastro, G. Casalino, P. Perulli, P. R. Spena, "Weldability of TWIP and DP steel dissimilar joint by laser arc hybrid welding with austenitic filler," Procedia CIRP, c. 67, ss. 607-611, 2018.

[3] Y Akinay, F Hayat, "Effect of Ni on the mechanical behavior of a high-Mn austenitic TWIP steel," Materials Testing, c. 58, s. 5, ss. 413-417, 2016.

[4] G. Casalino, A. Angelastro, P. Perulli, P. Posa, P. R. Spena, "Fiber laser-MAG hybrid welding of DP/AISI 316 and TWIP/AISI 316 dissimilar weld," Procedia CIRP, c. 79, ss. 153-158, 2019.

[5] F. Hayat and H. Uzun, "Microstructural and mechanical properties of dual-phase steels welded by GMAW process with solid and flux-cored welding wires," International Journal of Materials Research, c. 103, ss. 828-837, 2012.

[6] T. C. A. Colombo, R. R. Rego, J. Otubo, A. R. de Faria, "Mechanical reliability of TWIP steel spot weldings," Journal of Materials Processing Technology, c. 266, ss. 662-674, 2019.

[7] F. Hayat, "TRIP Çeliklerinin Otomotiv Endüstrisinde Kullanımının İncelenmesi,” Journal of The Faculty of Engineering and Architecture of Gazi University, c. 25, s. 4, ss. 701-712, 2010.

[8] Y. Akinay, F. Hayat, "The influence of the heat treatment on mechanical and microstructure properties of Fe-Mn-C high manganese steel," Kovove Materialy, Metallic Materials, c. 54, ss. 1-6, 2016. 
[9] W. Li, M. Vittorietti, G. Jongbloed, J. Sietsma, "The combined influence of grain size distribution and dislocation density on hardness of interstitial free steel," Journal of Materials Science \& Technology, c. 45, ss. 35-43, 2020.

[10] F. Hayat, H. Uzun, "Effect of Heat Treatment on Microstructure, Mechanical Properties and Fracture Behaviour of Ship and Dual Phase Steels," Journal of Iron and Steel Research, International, c. 18 , s. 8 , ss. $65-72,2011$.

[11] H. Chen, Z. He, L. Lu, "Correlation of surface features with corrosion behaviors of interstitial free steel processed by temper rolling," Journal of Materials Science \& Technology, c. 36, s. 1, ss. 37$44,2020$.

[12] C. Wang, Y. Yua, J. Yua,, Y. Zhang, Y. Zhao, Q. Yuan, "Microstructure evolution and corrosion behavior of dissimilar 304/430 stainless steel welded joints," Journal of Manufacturing Processes, c. 50, ss. 183-191, 2020.

[13] F. Hayat, "Resistance spot weldability of dissimilar materials: BH180-AISI304L steels and BH180-IF7123 steels," Journal of Materials Science \& Technology, c. 27, s. 11, ss. 1047-1058, 2011.

[14] J. Lia,, Q. Suna, Y. Liua, , Z. Zhen, Q. Sun, J. Fenga, "Melt flow and microstructural characteristics in beam oscillation superimposed laser welding of 304 stainless steel," Journal of Manufacturing Processes Volume, c. 50, ss. 629-637, 2020.

[15] W. H. Kearns, Welding Processes, AWS Welding Handbook, 3., 7. bask1, ., London, England: American Welding Society, Published by Macmillan Press Ltdss., 1980, ss. 1-55.

[16] Y. Akinay, F. Hayat, "Investigation of resistance spot welds between DP450 steel and aluminum alloys," Materials Testing, c. 58, s. 5, ss. 408-412, 2016.

[17] F. Hayat, B. Demir, M. Acarer, S. Aslanlar, "Adhesive weld bonding of interstitial free steel at spot welding for automotive application," Kovové Materiály Metallic Materials, c. 48, s. 2, ss. 137-143, 2010.

[18] F. Hayat, B. Demir, and M. Acarer, "Tensile Shear Stress and Microstructure of Low-Carbon Dual-Phase Mn-Ni Steels After Spot Resistance Welding," Metal Science and Heat Treatment, c. 49, ss. 9-10, 2007.

[19] I. Sevim, F. Hayat, M. K. Kulekci, "Nucleus geometry and mechanical properties of resistance spot welded coated-uncoated DP automotive steels," Bulletin of Materials Science, c. 36, s. 6, ss. 10491055, 2013.

[20] S. Aslanlar, "The effect of nucleus size on mechanical properties in electrical resistance spot welding of sheets used in automotive industry," Material Design, c. 27, s. 2, ss. 125-131, 2006.

[21] F. Hayat, B. Demir, M. Acarer, S. Aslanlar, "Effect of weld time and weld current on the mechanical properties of resistance spot welded IF (DIN EN 10130-1999) steel," Kovove Materialy, c. 47, s. 1, ss. 11-17, 2009.

[22] E. Kaluç, K. Tülbentçi, "Paslanmaz çelikler ve kaynaklanabilirliği," Seminer Notları, Kocaeli Üniversitesi Kaynak Teknolojisi Araştırma Eğitim ve Uygulama Merkezi, Kocaeli, Türkiye, 1995.

[23] B. Kocabekir, R. Kaçar, S. Gündüz, F. Hayat, "An effect of heat input, weld atmosphere and weld cooling conditions on the resistance spot weldability of 3161 austenitic stainless steel," J. Mater. Process. Tech., c. 195, s. 1- 3, ss. 327-335, 2008. 
[24] S. M. Manladan Yusof F., Ramesh S., Zhang Y., Luo Z., Ling Z., "Microstructure and mechanical properties of resistance spot welded in welding-brazing mode and resistance element welded magnesium alloy/austenitic stainless steel joints," Journal of Materials Processing Tech., c. 250, ss. 45$54,2017$.

[25] F. Hayat, "Comparing properties of adhesive bonding, resistance spot welding, and adhesive weld bonding of coated and uncoated DP 600 steel," Journal of Iron and Steel Research International, c. 18 , s. 9, ss. 70-78, 2011.

[26] F. Hayat, "Çift-fazlı çeliklerin nokta direnç kaynağında Mho ile kaynak süresinin mekanik özelliklere etkisi," Yüksek lisans tezi, Fen Bilimleri Enstitüsü, Zonguldak Karaelmas Üniversitesi, Karabük, Türkiye, 2005.

[27] A. Hasanbaşoğlu, R. Kaçar, "Resistance spot weldability of dissimilar materials (AISI 316LDIN EN 10130-99 steels)," Materials and Design, c. 28, ss. 1794-1800, 2007.

[28] B. Gülbahar, “\%17 Kromlu ferritik paslanmaz çeliklerin nokta kaynağında kaynak parametrelerinin tanelerarası korozyon ve çekme makaslama dayanımı üzerindeki etkisinin incelenmesi," Doktora tezi, Fen Bilimleri Enstitüsü, İstanbul Teknik Üniversitesi, İstanbul, Türkiye, 1989.

[29] Vural M., Akkuş A., "On the resistance spot weldability of galvanized interstitial free steel sheets with austenitic stainless steel sheets," Journal of Materials Processing Technology, ss. 1-6, 2004.

[30] O. Martin, P. D. Tiedra, M. Lopez, M. San-juan, C. Garcia, F. Martin, Y. Blanco, "Quality prediction of resistance spot welding joints of 304 austenitic stainless steel," Materials and Design, c. 30, s. 1, ss. 68-77, 2008.

[31] F. Hayat, B. Demir, S. Aslanlar, "Nokta Direnç Kaynak Süresinin IF 7114 Çeliği Birleştirmelerinin Mekanik Özelliklerine Etkisi,” IV. Demir Çelik Kongresi, Türkiye, 2007.

[32] Z. Almus, "Nokta direnç kaynağında ara bağlayıcının birleşme özelliklerine etkilerinin araştırılması," Yüksek lisans tezi, Fen Bilimleri Enstitüsü, Gazi Üniversitesi, Ankara, Türkiye, ss. 3-63, 2006. 